
ДОПРОФЕСІЙНОЇ ДІЯЛЬНОСТІ В БАГАТОНАЦІОНАЛЬНОМУ СЕРЕДОВИЩІ

rozvytku osobystosti [Spiritual values in the development of personality]. Pedagogy and psychology. No. 1(14), pp. 124-129. [in Ukrainian].

2. Bulavenko, S. D. (2019). Osvitno-informatsiinyi prostir dlia formuvannia sotsialno-aktyvnoi osobystosti [An educational and informational space for the formation of socially active personality]. An educational and methodical manual. Nizhyn. 314 p. [in Ukrainian].

3. Bulavenk, S. D. \& Kovalenko, Ye. I. (2018). Formuvannia sotsialnoi aktyvnosti uchniv[Formation of social activity of students]. An educational and methodical manual. Nizhyn, 224 p. [in Ukrainian].

4. Hurevych, R.S. \& Kademiia, M. Yu. (2005). Metodyka vprovadzhennia informatsiinykh tekhnolohii u navchalnyi protses : navch. posib.
[A method of introduction of information technologies into the educational process: teaching. manual]. Vinnytsia, 64 p. [in Ukrainian].

5. Zasoby informatsiino-komunikatsiinykh tekhnolohii yedynoho informatsiinoho prostoru systemy osvity Ukrainy : monohrafiia (2010). [Means of Information and Communication Technologies of the Single Information Space of the Ukrainian Education System: Monograph]. (Ed.).V. Yu. Bykov. Kyiv, 160 p. [in Ukrainian].

6. Kanishevska, L. V. (2011). Vykhovannia sotsialnoi zrilosti starshoklasnykiv zahalnoosvitnikh shkil-internativ u pozaurochnii diialnosti : monohrafiia [Upbringing of social maturity of senior pupils of general educational boarding schools by extracurricular activities: monograph]. Kyiv, 368 p. [in Ukrainian].

Стаття надійшла до редакції 21.06.2019

УДК [37.013.42:323.1]:364-43

DOI:

Юлія Рябова, кандидат педагогічних наук, викладач кафедри англійської мови Чорноморського національного університету імені Петра Могили

\title{
ОСНОВИ ТА ПРИНЦИПИ ПРОФЕСІЙНОЇ ПІДГОТОВКИ МАЙБУТНІХ СОЦІАЛЬНИХ ПРАЦІВНИКІВ ДО ПРОФЕСІЙНОЇ ДІЯЛЬНОСТІ В БАГАТОНАЦІОНАЛЬНОМУ СЕРЕДОВИЩІ
}

Статтю присвячено розкриттю теоретичних основ і принципів професійної підготовки майбутніх соиіальних прачівників до роботи в багатоначіональному середовищі. Автором проаналізовано різні приниипи сочіальної роботи і виділено ті принципи, які необхідні для роботи в багатонаціональному середовищі України. В сочіальній роботі функиіонує велика сукупність складних, різноманітних зв 'язків і відносин, приниипи соиіальної роботи мають системний характер. Автор зазначає, щзо в нашій краӥні, як $і$ в інших краӥнах світу питання полягає в тому, що навчання соціальній роботі не може тільки пасивно відображати соціальний розвиток, воно повинно вести активний пошук шляхів вирішення соиіальних проблем.

Ключові слова: теоретичні основи і принциии; багатоначіональне середовище; професійна діяльність; сочуіальний працівник; професійна підготовка.

Jim. 10.

Yuliya Ryabova, Ph.D.(Pedagogy), Senior Lecturer of the English Language Department Petro Mohyla Black Sea National University

\section{FOUNDATIONS AND PRINCIPLES OF FUTURE SOCIAL WORKERS TRAINING TO THE PROFESSIONAL ACTIVITY IN THE MULTINATIONAL ENVIRONMENT}

The article is devoted to the theoretical foundations and principles of future social workers training to work in a multicultural society. The author analyzes the different principles of social work and highlights the principles that are necessary to work in a multicultural society of Ukraine. In social work there is a large set of complex, diverse relationships and connections, the principles of social work have systemic nature. The author notes that in our country, as in other countries of the world, the question is that teaching of social work can not only passively reflect social development, it has to be an active search of ways which can help to solve social problems.

One of the most important issues for Ukrainian society is the establishment of positive relations between people in a multinational society. Prevention of interethnic conflicts and solution of different problems are necessary issues that can provide high-quality training for future social workers who intend to regulate intercultural relations, provide conditions for the development of the individual and use socio-cultural knowledge and communication skills in the process of communicating with representatives of different cultures and social groups. Social work learning should be based on its own conceptual model. It is clear that in the process of social workers' training it is necessary to take into account the economic and social situation in the country; because in fact they affect the 


\section{ОСНОВИ ТАПРИНЦИПИПРОФЕСІЙНОӤПІДГОТОВКИ МАЙБУТНІХСОЩАЛЬНИХ ПРАЦІВНИКІВ ДОПРОФЕСЙ̆НОЇ ДІЯЛЬНОСТІ В БАГАТОНАЦІОНАЛЬНОМУ СЕРЕДОВИЩІ}

essence of social activity and the system of requirements that will be presented to the specialists of social work. There is a large set of complex, diverse relationship and the principles of social work. Principles of social work are important structural components of the logical forms of scientific theory and the theoretical positions directly correlate with social work practice.

Keywords: theoretical foundations and principles; multicultural society; professional activity; social worker; training.

П

остановка проблеми у загальному вигляді та її зв'язок із важливими науковими чи практичними завданнями. Політичні, соціально-економічні, демографічні та геополітичні зміни, що відбуваються в Україні, корінним чином змінюють соціальне життя суспільства. В таких умовах стає необхідною діяльність соціальних служб, що покликані допомогти суспільству подолати труднощі, пов'язані з вирішенням соціальних, психологічних та етнічних проблем. Сьогодні одним 3 найголовніших питань для українського суспільства є налагодження позитивних стосунків між людьми в багатонаціональному середовищі, попередження і профілактика міжетнічних конфліктів, а для вирішення цього питання $\epsilon$ необхідною якісна підготовка майбутніх соціальних працівників, які покликані регулювати міжкультурні відносини, забезпечувати умови для розвитку особистості та використовувати соціокультурні знання й навички комунікативної поведінки у процесі спілкування з представниками різних культур та соціальних груп.

Аналіз основних досліджень і публікацій. Теоретичним основам і принципам професійної підготовки соціальних працівників приділяється увага таких українських дослідників А. Капської, В. Поліщук, Т. Семигіної, І. Григи, І. Звєрєвої, Л. Коваль, С. Хлєбіка та ін. Теорії та методики підготовки спеціалістів до соціальної роботи висвітлено в працях таких російських вчених як Ю.Н. Галагузова, Л.Г. Гуслякова, Л.В. Топчий, В.И. Жуков, В.А. Никитин.

Деякі українські вчені приділяють увагу різним аспектам професійної підготовки майбутніх соціальних працівників у інших країнах, так наприклад Л. Віннікова приділяє увагу системі підготовки соціальних працівників у вищих навчальних закладах США, Н. Гайдук професійній підготовці соціальних працівників до здійснення посередництва (на матеріалах США і Канади), Н. Видишко професійній підготовці майбутніх соціальнихпрацівників уколеджах Канади, О. Пришляк аналізує стан системи професійної підготовки соціальних педагогів у Німеччині.

Теоретичні основи соціальної роботи висвітлено в працях зарубіжних вчених В. Робінсона, Дж. Тарта, О. Ранка, Г. Гамільтона, Ф. Бістека, Х. Нортена, М. Росса, М. Річмонда, Р. Перлмана та інші.
Формулювання цілей статті полягає у визначенні теоретичних основ та принципів професійної підготовки майбутніх соціальних працівників до роботи у багатонаціональному середовищі.

Виклад основного матеріалу дослідження. Підготовка майбутніх соціальних працівників у ЗВО України здійснюється на основі Державного галузевого стандарту спеціальності "Соціальна робота". Водночас вища освіта студентів цього фаху розглядається науковцями шляхом аналізу особливостей професійного навчання соціальних працівників в Україні. Визначення перспектив та формування системи підготовки та підвищення кваліфікації діагностики професійних здібностей, системи фахового відбору, визначення професійних ролей i функцій соціального працівника, формування професіоналізму й духовно-морального портрету особистості соціального працівника, формування професійної моделі соціального працівника та аналізу ii окремих компонентів: професійної комунікативної компетентності, толерантності, гуманності [3].

Підготовка соціальних працівників здійснюється в Україні на трьох рівнях: базовому, середньому та вищому - університетському [3, 38].

Соціальна робота в будь якій країні передбачає навчання тих, хто збирається нею займатися. Характер і форми цього навчання надзвичайно різноманітні, що відображає специфіку соціальної роботи якпрофесійної діяльності в різних країнах [10].

Навчання соціальній роботі повинно базуватися на власній концептуальній моделі. Закономірно, що в процесі підготовки соціальних працівників необхідно враховувати і опиратися на економічну та соціальну ситуацію в країні; адже власне вони впливають на сутність соціальної діяльності і на систему вимог, що пред'являтимуться до професійних працівників цієї професії [8].

Сьогодні в нашій країні, як і в інших країнах світу питання полягає в тому, що навчання соціальній роботі не може тільки пасивно відображати соціальний розвиток, воно повинно вести активний пошук шляхів вирішення соціальних проблем, що з'являються. Професіоналів для соціальної сфери потрібно готувати таким чином, щоб вони були здатні змінити, усунути і коректувати негативні соціальні прояви у суспільстві [6]. 


\section{ОСНОВИ ТАПРИНЦИПИПРОФЕСІЙНОӤПЦДГОТОВКИМАЙБУТНІХСОЩІАЛНИХ ПРАЦІВНИКІВ ДОПРОФЕСІЙНОӤ ДІЯЛЬНОСТІ В БАГАТОНАЦІОНАЛЬНОМУ СЕРЕДОВИЩІ}

В соціальній роботі функціонує велика сукупність складних, різноманітних зв'язків і відносин, принципи соціальної роботи мають системний характер. Їх можна звести у три групи: соціально-політичні; організаційні; психологопедагогічні $[1 ; 2 ; 5]$. Перші виражають вимоги, що випливають із науково обгрунтованого змісту соціальної політики держави. Це державний підхід до завдань, що розв'язуються у соціальній роботі, гуманізм і демократизм соціальної роботи, тісний зв'язок змісту й форм цієї роботи з конкретними умовами життєдіяльності особи, соціальної групи, законність і справедливість соціальної роботи [9].

Принципи соціальної роботи - це не приблизні абстракції чи суб'єктивні умовиводи. Вони об'єктивні за змістом і суб'єктивні лише за формою. Люди формулюють їх для того, щоб повсякденна практика не суперечила наявним соціальним закономірностям і водночас була раціональною, економічною та ефективною [4].

Принципи соціальної роботи це важливий структурний компонент логічних форм наукової теорії, завдяки яким теоретичні положення безпосередньо співвідносяться із практикою соціальної роботи $[5 ; 6]$.

Є.I. Холостова під принципами соціальної роботи розуміє “основоположні правила емпіричної діяльності” [7].

B.I. Курбатов класифікує принципи соціальної роботи враховуючи той факт, що соціальна робота $\epsilon$ універсальним видом діяльності i має міждисциплінарний характер, іiі методологічними принципами є інтеграційні принципи інших наук [2; 3]:

- Загальнофілософські принципи, які лежать в основі усіх наук про суспільство, людину і механізми їх взаємодії: принципи детермінізму, відображення, розвитку.

- Загальні принципи соціальних (суспільних) наук, принципи історизму, соціальної обумовленості, соціальної значимості, гносеологічного підходу, єдності свідомості та діяльності; соціально-політичні, організаційні, психолого-педагогічні тощо.

- Соціально-політичні принципи виявляють вимоги, що зумовлені залежністю змісту I спрямованості соціальної роботи від соціальної політики держави. Ця залежність визначає концептуальні підходи до вибору пріоритетів у соціальному захисті населення, до поєднання індивідуальних і загальних інтересів в соціальній роботі. До основних принципів цієї групи належать: єдність державного підходу у поєднанні 3 регіональними особливостями соціальної роботи, демократизм п змісту і методів, врахування конкретних умов життєдіяльності особистості чи соціальної групи при виборі змісту, форм і методів соціальної роботи з ними, законність і справедливість діяльності соціального працівника [1].

- Організаційні принципи - соціальнотехнологічна компетентність кадрів, принципи контролю і перевірки виконання, функціональної визначеності, єдності прав і обов'язків, повноважень і відповідальності [8].

- Психолого-педагогічні принципи виявляють вимоги до добору засобів психологопедагогічного впливу на клієнтів соціальних служб, необхідність врахування індивідуальних характеристик при здійсненні будь-яких технологічних процесів. До основних принципів цієі групи належать: комплексний аналіз оцінювання умов життєдіяльності клієнтів і вибору форм роботи 3 ними; індивідуальний підхід; цілеспрямованість і адресність соціальної роботи [9].

- Специфічні принципи соціальної роботи визначають основні правила роботи у сфері надання соціальних послуг населенню: принципи гуманізму, справедливості, комунікативності, варіативності соціальної допомоги, гармонізації суспільних групових і особистісних інтересів тощо [10].

А.Й. Капська зазначає, що соціальнопедагогічна діяльність тісно взаємопов'язана 3 різними соціальними інститутами виховання та галузями суспільної практики, відповідно до цього вона функціонує як розгалужена сукупність зв'язків та відносин в соціальній сфері. Тому А.Й. Капська зазначає, що принципи соціальної роботи представляють собою певну систему, до складу якої можна віднести [5, 30]:

- Соціально-політичні принципи. До соціальнополітичних принципів А.Й. Капська відносить принцип законності та прав людини, призначення якого полягає в забезпеченні державою та відповідними соціальними інститутами реалізації положень документів стосовно прав людини, ратифікованих нашою державою $[5,30]$. Принцип державного підходу до завдань що реалізуються в соціальній і соціально-педагогічній діяльності підкреслює активну роль держави в постановці пріоритетних завдань та організації соціального виховання. Принцип зв'язку змісту і форми діяльності фахівця соціальної сфери з конкретними умовами життєдіяльності особистості чи соціальної групи має на меті адресну організацію допомоги та підтримки, обумовлену соціальноекономічними, соціально-політичними та соціально-культурними умовами макро та мікросередовища об'єкта соціально-педагогічпої діяльності [5, 31]. 


\section{ОСНОВИ ТАПРИНЦИПИПРОФЕСІЙНОӤПІДГОТОВКИ МАЙБУТНІХСОЩАЛЬНИХ ПРАЦІВНИКІВ ДОПРОФЕСІЙНОӤ ДІЯЛЬНОСТІ В БАГАТОНАЦІОНАЛЬНОМУ СЕРЕДОВИЩІ}

\begin{abstract}
- Психолого-педагогічні принципи. Дояких вона відносить принцип сприяння самореалізації дітей та молоді у всіх сферах їх життедіяльності. Він забезпечує здійснення соціального впливу як створення умов для саморозвитку особистості. Принципи диференційованого та індивідуального підходу до об'єктів соціальної та соціальнопедагогічної діяльності, який базується на відповідних принципах класичної педагогіки. Принцип цілеспрямованості полягає в тому, що фахівець повинен цілеспрямовано досягати професійної мети, впливаючи на свідомість, почуття, волю та вчинки людей. Принцип системності. Соціальна і соціально-педагогічна діяльність завжди виступає як певний планомірний процес, що вимагає єдності форм, засобів та прийомів вирішення різних професійних завдань $[5,31]$.
\end{abstract}

- Організаційні принцип компетентності кадрів, перш за все, підкреслює обов'язковість професійної підготовки спеціалістів. Це забезпечують знання психології, соціальної педагогіки, соціології, менеджменту та інших дисциплін, що виступають підгрунтям фахової обізнаності спеціаліста. До нього відноситься Принцип інтеграції, який забезпечує координацію діяльності державних, громадських та інших організацій стосовно вирішення соціальнопедагогічних проблем. Принцип контролю та перевірки виконання, який забезпечує реалізацію гарантованих державою заходів щодо соціального захисту різних груп населення [5, 32].

- Специфічні принципи соціально-педагогічної діяльності до яких А.Й. Капська відносить принцип гуманізму, який має па меті здійснення соціально-педагогічної діяльності на засадах альтруїзму, емпатії, людяності, прийняття особистості клієнта 3 усім його позитивом та негативом. Принцип незалежності означає, що об'єктами соціально-педагогічної діяльності $є$ всі, хто потребує допомоги та підтримки, виключаючи, дискримінацію за ̈̈х ідеологічними, політичними, релігійними, національними, віковими особливостями. Принцип клієнтоцентризму визнає пріоритет прав клієнта в усіх випадках, крім тих, в яких це суперечить правам та інтересам інших людей. Принцип опори на потенційні можливості людини, підкреслює активну роль клієнта у вирішенні власних проблем. Принцип конфіденційності який означає, що в процесі професійної діяльності спеціалісту стає відомо різноманітна інформація, довірена йому клієнтом. Принцип толерантності полягає в тому, що соціальний працівник працює з різними групами клієнтів, в тому числі з особами, яким він з різних об'єктивних та суб'єктивних причин не симпатизує. Принцип максимізації соціальних ресурсів виходить 3 того, що кожна держава виділяє певну кількість коштів на реалізацію соціальної політики [5, 33 - 34].

I.I. Мигович виділяє наступні принципи соціальної роботи: принцип стимулювання, який передбачає єдність і застосування ідейноморальних та матеріальних форм, засобів і способів, а також індивідуальних, професійних, культурних та психологічних особливостей клієнта. Принцип гуманізму соціальної роботи передбачає визнання людини найвищою цінністю, захист ії гідності й громадянських прав, створення умов для вільного і всебічного виявлення здібностей кожного [3].

Одним з основних принципів соціальної роботи на думку І.І. Миговича є її законність. Він відмічає, що цей принцип передбачає суворе дотримання законів і відповідних правових актів усіма державними органами, посадовими особами, громадськими організаціями і громадянами [3].

Висновки 3 даного дослідження i перспективи подальших розвідок у даному напрямку. На нашу думку одними 3 найважливіших принципів соціальної роботи необхідних для діяльності у багатонаціональному середовищі є принципи: законності та прав людини, толерантності, гуманізму, комунікативності, універсальності, охорони соціальних прав, конфіденційності та соціального реагування.

Отже перед соціальною освітою в Україні стоїть складне завдання покращити складну ситуацію сьогодення, поставивши в центрі уваги людину, чия безпека та життєвий рівень, права i благоустрій повинні бути покращені, а проблеми які виникають вирішені. Томунавчання соціальній роботі повинно відігравати провідну роль у вищих навчальних закладах нашої держави. Для вирішення цього завдання потрібен весь досвід, знання, які нагромаджені в нашій країні і закордоном і які соціальні працівники повинні навчитися використовувати на практиці і розвивати у подальший професійній діяльності.

\section{ЛІТЕРАТУРА}

1. Карпенко О. Г. Професійна підготовка соціальних працівників в умовах університетської освіти: науково-методичний та організаційнотехнологічний аспекти : Монографія /за ред. С.Я. Харченко. Дрогобич, 2007. 374 с.

2. Курбатов В.І. Соціальна Робота. Ростов Н/ Д, $1999.576 \mathrm{c}$.

3. Лукашевич М. П., Мигович І. І. Навч. посіб. 2-ге вид., доп. і випр. Київ, 2003.168 с. 
4. Соціальна робота в Україні: Навч. посіб. / І.Д. Зверева, ОВ. Безпалько, СЯ. Харченко та ін.; За заг. ред. І.Д. Звєрєвої, Г.М. Лактіонової. Київ, 2004. $256 \mathrm{c}$.

5. Соціальна робота: технологічний аспект: Навчальний посібник / За ред. А.И. Капської. Київ, $2004.352 \mathrm{c}$.

6. Технологии социальной работы/Е.И. Холостова, П. Д. Павленок, В. Ц. Худовердян,Т. В. Шеляг. Москва, 2003. 399 с.

7. Холостова Е. И. Профессионализм в социальной работе: Учебное пособие. 3-е изд. Москва, 2009. 236 с.

8. Шерстюк Л.В. Сутність та основні структурні компоненти міжкультурної компетенції студентів. Наукові праці : наук журн. / Чорном. нац. ун-тім. ПетраМогили; ред. кол. :О.П. Мещанінов (голова) та ін. Миколаїв, 2017. Т. 303. Вип. 291. C. 96-101.

9. Gryshkova R.O. Specifics of teaching professional English to non-philological students at high school. - Modern tendencies in pedagogical education and science of Ukraine and Israel: the way to integration. - Ariel University, Israel. № 62015. pp. 107-112.

10. Social Work with Marginalized Persons in the Social Community - the Experiences of Poland and Norway. Warsaw: Academy of Special Education Publishing House, 2011. 171 p.

\section{REFERENCES}

1. Karpenko, O. H. (2007). Profesiyna pidhotovka sotsial'nykh pratsivnykiv $v$ umovakh universytetskoyi osvity: naukovo-metodychnyy ta orhanizatsiynotekhnolohichnyy aspekty [Professional training of social workers in the conditions of university education: scientific-methodical and organizationaltechnological aspects]. (Ed.). S. Ya. Kharchenko. Drohobych, 374 p. [in Ukrainian].
2. Kurbatov, V.I. (1999). Sotsialna robota [Social work]. Rostov N/D, 576 p. [in Russian].

3. Lukashevych, M. P. \& Myhovych, I. (2004). Navch. Posib [Teaching manual]. Vol.2 Kyiv, 168 p. [in Ukrainian].

4. Kharchenko, S.Ya., Zvereva, I.D. Bezpalko, O.B. et al. (2004). Sotsialna robota v Ukrayini [Social work in Ukraine]. (Ed.).I.D. Zvyeryeva, H.M. Laktionova. Kyiv, 256 p. [in Ukrainian].

5. Sotsialna robota: tekhnolohichnyy aspekt: [Social Work: Technological Aspect]. Teaching manual (Ed.).A.Y. Kapska. Kyiv, 352 p. [in Ukrainian].

6. Kholostova, Ye. I., Pavlenok, P. D., Khudoverdyan, V. Ts. \& Shelyag, T. V. (2003). Tekhnologii sotsialnoy raboty [Technologies of social work]. Moscov, 399p. [in Russian].

7. Kholostova, Ye. I. (2009). Professionalizm v sotsialnoy rabote [Professionalism in social work]. A study guide the third edition. Moscov, 236 p. [in Russian].

8. Sherstyuk, L.V. (2017). Sutnist ta osnovni strukturni komponenty mizhkulturnoyi kompetentsiyi studentiv[The essence and the basic structural components of intercultural competence of students]. Scientific works: scientific journal. Black Sea National University named after Petro Mohyla. Mykolayiv. Vol. 303, issue. 291, pp. 96-101. [in Ukrainian].

9. Gryshkova R.O. (2015). Specifics of teaching professional English to non-philological students at high school. Modern tendencies in pedagogical education and science of Ukraine and Israel: the way to integration. Ariel University, Israel. No. 6, pp. $107-$ 112. [in English].

10. Social Work with Marginalized Persons in the Social Community - the Experiences of Poland and Norway. Warsaw: Academy of Special Education Publishing House, 2011. 171 p. [in English].

Стаття надійшла до редакції 30.05.2019

\section{G58089}

“Же важливо, наскільки повільно ти рухаєшся вперед доти, поқи ти не зупиняєщся”. Конбуüiü давньокитайський білособ

"Була бмета поставлена - а ланцюжок проб $і$ помилоксам приведе до бажаного результату".

Харукі Мурақамі японсъжий писъменник і перекладач

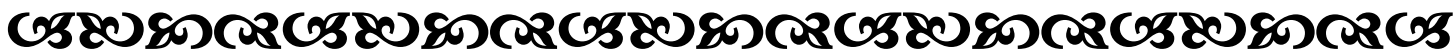

